\title{
ASSESSING THE ACQUISITION OF INFORMATION QUESTIONS IN ENGLISH MADE BY THE ELEVENTH GRADE STUDENTS OF SMK SARASWATI DENPASAR IN ACADEMIC YEAR 2009/2010
}

\author{
Dewa Gede Agung Gana Kumara \\ English Education Department, Faculty of Education and Teacher Training \\ University of Mahasaraswati Denpasar
}

\begin{abstract}
This study was undertaken in order to assess the acquisition of information questions by the eleventh grade students of SMK Saraswati Denpasar in academic year 2009/2010. The undertaking of the study was motivated by the fact that information questions are the fundamental basis of good communication skills in English. This study was intended to answer the research question: To what extent is the acquisition of the eleventh grade students of SMK Saraswati Denpasar in constructing information question in English. This study made use of an ex-post facto research design. The population of the study was the eleventh grade students of accountancy department which consists of two classes with the total students of 79 altogether. They were considered to have homogeneous characteristic. In this study, only 40 students were determined as the objects by using quota random sampling technique with lottery system. The data obtained in the study which were in the form of raw scores showing the subjects' acquisition of information questions of the eleventh grade students of SMK Saraswati Denpasar, were analyzed with norm reference measure with five standard values. It clearly showed that: (1) there are 5 subjects $(12.5 \%)$ out of 40 subjects under study who got excellent ability in asking information questions in English, (2) there are 11 subjects (27.5\%) out of 40 subjects under study who got good ability in asking information questions in English. (3) there are 13 subjects (32.5\%) out of 40 subjects under study who got sufficient ability in asking information questions in English and (4) there are 11 subjects $(27.5 \%)$ out of 40 subjects under study who got insufficient ability in asking information questions in English. In general these research findings revealed that the acquisition of information questions by the eleventh grade students of SMK Saraswati Denpasar is remarked as good, where the number of subjects who got insufficient acquisition in information questions were under 50\% or half of the number of subjects understudy. The number of students who got insufficient acquisition in information questions is only 11 subjects or $27.5 \%$ out of 40 subjects understudy. The findings of the study have limited validity and reliability, because it made use of an ex-post facto research design. Therefore, the research findings should be carefully depended upon.
\end{abstract}

Key Word: Acquisition, ex post facto, Norm Reference Measure 


\section{INTRODUCTION}

Language has a very important role in human life. Language is used to communicate, to express our idea and felling or conveying a message from a writer to a reader, from speaker to a listener. Without language, we cannot communicate with others. One of the languages used in communicating with one another is English. English is used as means of mutual relationship among nations, for trade and commerce tourism and traveling. English is the world's most important language. Some other linguists stated that English is a Lingua franca. Harmer (1991:01) states that a lingua franca can be defined as a language widely adopted for communication between two speakers whose native languages are different from each other's and where one or both speakers are using it as a second language. This means that English is the major language used in the world. It is used worldwide as means of communication.

In Indonesia, English is used as the first foreign language to be taught and learnt as compulsory subject from Primary School until University after the National Official Language of Indonesian language. The purpose of the teaching English in Indonesia based on the Indonesia Curriculum for Vocational School is to equip the students with good and fluent communication skills. By having good and fluent communication skills, it is expected that we can establish good relationship with other countries in all kinds of affair such as commerce, education, culture, tourism, etc. Therefore, by mastering English, we will certainly be able to communicate with people from many different countries. Students in Bali, especially have many opportunities to communicate to people from many different reasons. Considering that Bali is one of the islands which many people from different countries come to spend their time for doing business or vacation. It is a good opportunity for student in Bali to communicate with native speaker directly while they develop their ability in using English.

The principle of good communication if persons who in a conversation or communication understand each other. Other people will understand us if we formulate and arrange the words appropriately. This means that we must master the grammatical structure of English correctly. The mastery of grammatical structures makes us easier to develop the four skills, namely speaking, reading, listening and 
writing. By mastering the four language skills, we will be able to communicate in English well. The ability of the students in communicating in English is often judged through their communicative performance of their real ability to communicate in English both in and outside the classroom. In fact, we will be easily judging other people by listening to their performance in English, whether they can perform the language well or not in asking and answering question.

Many years have been spent in learning English and many scientific studies have been conducted in order to answer the question how to acquire the foreign language easily including how to formulate a structural English question; however, there are still so many students cannot formulate a good structural English question. There are still many students who have difficulties in formulating good questions. One of the main problems is the difficulties in constructing and answering question. The difficulties are not only found in forms (making correct questions and giving correct answers) but also in meanings (asking and answering the right questions). For instance when the students form a simple question ask about reason 'Why didn't he go to school yesterday?' In this case students sometime confuse in placing and using the auxiliary verb. The incorrect question form usually occurs from the students is: 'Why he didn't go to school yesterday?' the idea of the question is correct but the construction is wrong. In this question, the auxiliary verb 'didn't' has to be added before the subject. The errors are not only occurring in forming a question but also in meaning. In asking and answering the question, the students have difficulties when starting a question. They are difficult to differentiate which question-word is used for asking subject, object, reason, place, time, choice or measurement. So, when they express their ideas in a question, sometimes the meaning of the question will be different with their idea. For example, in a statement 'John's father is an English teacher', the students need information about John's father occupation but they use a wrong question word, e.g. 'Where is John's father?' so the meaning of question will be different. The questions should be 'What is John's father?'

The curriculum designed for Vocational Schools also covers grammar that includes Information Questions. The students are actually expected to be able to communicate with other people, especially foreign tourist who come to Bali. However, the same problem is found in formulating and answering information 
questions. This can be proved in the teaching and learning process. The students intend to communicate their ideas by means of oral and written form in asking and answering questions, however, as far as the researcher knows, they still make many mistakes in formulating their questions and answers, especially the Information questions.

Concerning the matter above, the researcher intends to conduct a study on the students' acquisition in asking and answering the information questions. This research is conducted in order to see the students' mastery of the information questions. The researcher is interested in this matter because based on his experience when he did teaching practice. He could see that information question is one of the most difficult parts of English to be learned and therefore the students make so many mistakes. He could see that the student have difficulties in formulating correct questions and answers. Therefore, the writer would like to conduct a study under the title: assessing the acquisition of information question in English made by the eleventh grade students of SMK Saraswati Denpasar in academic year 2009/2010.

\section{Statement of Research Question}

Based on the background of the study above, the problem of the study could be formulated as follows: to what extent is the acquisition of the eleventh grade students of SMK Saraswati Denpasar in constructing information question in English?

\section{Objective of Study}

A scientific investigation is conducted to solve the research question. In reference to the statement of the research question formulated and stated previously, the present study intends to reveal the degree of ability of the eleventh grade students of SMK Saraswati Denpasar in constructing information question in English.

The establishment of the findings of the present study is expected to provide informative feedback to the English teachers and students about their level and ability and about their successfulness and failure in learning and acquiring information question. 


\section{Foreign Language Acquisition}

It is difficult to choose the suitable term, whether language learning or language acquisition in term of studying English language. Many linguist and psychologist at the present time prefer to talk about acquisition rather than the learning of language. Acquisition is also in the context of learning foreign language. Foreign or second language acquisition is thus distinguished from first language and mother language. Richard (1985:3) states that the process by which a person learns a language is sometimes called acquisition instead of learning. Titony and Daneshy (in Roku, 2007:09) define language acquisition as a subconscious creative construction process used by children in acquiring first and second language, as well as by adult. There is different between language acquisition and language learning. The former is automatic the latter is controlled. A different between the two can be illustrated by comparing the speech of second language learner in structured and free learning situation. In such structured learning situation as drill and exercises, learners are capable of using with a high degree of accuracy. In other word, language acquisition is automatic while language learning is controlled. Learning is conscious process of rules internalization, which results either from overt teaching or from a self-study of linguistic rules. Unlike acquisition, learning profits from error correction and rule explanation.

\section{The Conception of Questions}

In communicating with one another, whether it is oral or written will occur one or more unites called sentences. Hornby (1973:794) writes that a sentence is grammatically arranged words, especially with subject and predicate, that form a statement, question or request making a complete sense. Sentences may be divided into four major syntactic classes; they are statements, directives, exclamations and questions.

Questions is sentences which by word order use of interrogative words (who, when, why, etc.) or intonations to request information or answer (Hornby, 1973:796). Question is also called interrogative sentence. In writing, interrogative sentences are always ended by a question mark (?). In classrooms, questions take an important part of teaching and learning process, by asking questions to students, the teacher may 
help the students to encourage their mental activities and also to attract their attention. Turner (in Surata, 1997:17) believe that through questions, teachers find out what the students know or think and how to stimulate them to think and help them the structure and change their thinking. In using questioning technique, the questions should not mainly come from the teacher him self, but students should be asked to make questions related to the passage being discussed. Penny Ur (1996:229) adds that the reason of questions in general as follows: (1) to provide a model for learning and thinking, (2) to find out something from learners (facts, ideas, opinions), (3) to check or test understanding, knowledge or skill, (4) to get learners to be active in their learning, (5) to direct attention to the topic being learned, (6) to inform the class via the answers of the stronger learner rather than through the teacher's input, (7) to provide weaker learners with an opportunity to participate, (8) to stimulate thinking (logical, reflective or imaginative); to probe more deeply into issues, (9) to get learners to review and practice previously learnt material, (10) to encourage self expression, (11) to communicate to learner that the teacher is genuinely interested in what they think.

\section{The Importance of Questioning Skills}

The questioning skills are very essential, especially in the process of teaching and learning. The good questions will be extremely useful to improve the participations of the students in teaching and learning process. Penny Ur (1988:34) states that there are several reasons for questioning: (1) To give the teacher information about where the students are at the moment to help what to teach next; (2) To give the students information about what they know, so that they also have an awareness of what they need to learn or review; (3) To assess for some purpose external to current teaching (a final grade for the course, selection); (4) To motivate the students to learn or review specific material; (5) To get noisy class to keep quite and concentrate; (6) To provide a clear indication that the class as reached a station in learning, such as the end of unit, the thus contributing to a sense of structure in the course as a whole; (7) To get a students make an effort, which is likely to a better result and a feeling satisfaction; (8) To give students task with them selves may 
actually provide the useful review or practice as well as testing; (9) To provide students which a sense of achievement and progress in their learning.

In order to be successful in the teaching learning process, the competence in questioning is very important. Haysom (1974:42) says that questioning is not purely an intellectual activity there is an emotional element to it as well. Difficult questions can demoralize as well as challenge. Easy question can irritate as well as given a feeling of success. The effects of questions on the pupils are clearly important if the questions are to achieve the purpose of helping pupils to think. The teacher should plan questions carefully.

Haysom (1974:42) further states that apart from asking questions stimulating the pupil to remember information, the teacher might prompt the pupils to solve problems, to make hypothesis, to design experimental procedure, to observe, to interpret, to draw references and so on.

The questioning skills are not only for the teacher but also for the students. In order the teaching process runs well the students should be active. They are not just as listeners but they have to express their opinion or idea by asking some questions. To be good questioner the students should have good questioning skills. Therefore they have to know how to construct questions especially Information Questions or WH-Questions, for instance the students should ask some questions if they do not understand the teacher' explanation. In this case, the questioning skills of the students are very useful.

\section{Significance of the Study}

The results of the present study are expected to bear the following importance:

1. Theoretically, the finding of this study, which shows the degree of questioning and answering ability of the subject under study are expected to contribute further empirical evidences concerning the existing similar research finding which have revealed the important rule of grammatical competence, especially the important rules of constructing information question.

2. Practically, the finding of the study can give useful informative feedback to English teachers especially concerning their relative success and failure in 
teaching structures include information questions. Hopefully, the findings of the study could be used as the bases in planning better communicative language teaching in the future. This is important since a good English teacher should be ready and willing to learn from his previous success and failure.

3. The findings of the present investigation are further intended as informative feedback to the students of English. In this case they are certainly expected to be much inspired and motivated to acquire communicative skills in constructing and practicing information question.

\section{RESEARCH METHOD}

The present investigation made use of an ex post facto research design with descriptive analysis. Kerlinger in Wiersma (1980:134) writes that an ex post facto is systematic empirical investigation in which the researcher cannot directly control or manipulate the confounding independent variables because the manifestations have already taken place before the study was conducted. This means that the investigated variable in this research, the questioning skills of the population that is the eleventh grade students of SMK Saraswati Denpasar has already occurred. In the sense that before the present study was undertaken, they have been learning and acquiring some basic grammatical rules or patterns of how to effectively construct and ask information question through classroom discourses or conversation outside the classroom. In the other word, this study did not intend to examine the extent of relationship between dependent and independent variables. Thus, this study simply investigates the questioning ability of the subject under study and the confounding independent variables were completely ignored.

\section{RESULT AND DISCUSSION}

The results of the data analysis clearly showed that (1) there were only 5 students $(12.50 \%)$ out of the investigated subject who showed excellent ability in asking information questions in English, (2) there were 11 students (27.50\%) out of the investigated subject who showed good ability in asking information questions in English, (3) there were 13 students $(32.50 \%)$ out of the investigated subject who 
showed sufficient ability in asking information questions in English, (4) there were 11 students $(27.50 \%)$ out of the investigated subject who showed insufficient ability in asking information questions in English. If the result of the study were used as the bases to assign grade to the students under study, then there are 11 students out of 40 students who fail in the learning and acquiring information questions in English. This means that $27.50 \%$ of them still have low ability. The findings of the present investigation can be remarked as satisfactory. Although there are 11 students (27.5\%) have low ability in constructing information questions in English and needs to be increased.

These finding can be used as informative feedback in planning much better communicative language teaching in the future. In this case, the students should be given more chance to be active in the teaching learning process. They are encouraged to be able to make questions using the construction of information questions in order to gain certain information. This can be done in the conversation between the students and the teacher or among the students. So that they are forced to construct questions particularly information questions based on the given patterns.

There are a lot of factors which might significantly affect the ability of the eleventh grade students of vocational high school SMK Saraswati Denpasar in constructing information questions in English. These factors are simply beyond the control of the present study. Some of the determinant factors affecting the students' ability are the motivation of the students in learning English subject, their attitude towards the English subject, their aptitude in English, their linguistic environment and the qualification of the teachers. The teachers' factors indeed play important roles in bringing the students towards the achievement of learning objectives, the ability in constructing information questions in English. The teachers' qualification or competence in English is very important. As a matter of fact, the teachers are the most powerful and influential persons in the classroom. In other words qualified and skillful English teachers are certainly able to choose and manipulated different kinds of classroom techniques. The use of appropriate and conducive classroom techniques is promotion for the students in learning English. So the success or the failure of the students in constructing information questions depends on the above factors. Thus, we cannot only blame the English teachers. Since the present study is administered in 
the private vocational high school, the findings of the investigation are only for that school. It means that the result of the findings can not be generalized to other vocational school.

\section{CONCLUSIONS}

The discussion throughout the present investigation can finally be concluded that the results of the data analysis using norm-references measure of five standard values clearly show that: (1) 5 subjects $(12.5 \%)$ out of the whole subjects get excellent grade in constructing information questions in English, (2) 11 subjects $(27.5 \%)$ out of the whole subjects get good grade in constructing information questions in English, (3) 13 subjects (32.5\%) out of the whole subjects get sufficient grade in constructing information questions in English, (4) 11 subjects (27.5\%) out of the whole subjects get insufficient grade in constructing information questions in English. These findings suggest that the degrees of the ability of the eleventh grade students of vocational high school SMK Saraswati Denpasar are good enough in constructing information in English.

In this case, the researcher fully realized that there are inherently some factors which affect the ability of the students in constructing information questions in English which are simply beyond the control of the present study, such as the students' motivation in learning English, their aptitude in English, their linguistic environments and also the qualification and the competence of the teacher in English.

The findings of the present study can be used as bases in planning much better communicative language teaching especially in teaching information question (Whquestion) at SMK Saraswati Denpasar particularly in the future. By knowing the students' ability in constructing information questions in English, the teacher can plan next lessons in two ways that is (1) remedial for the insufficient and poor grade students, (2) improvement for those who get excellent, good and sufficient grade.

\section{SUGGESTION}

In reference to the findings of the present study then the researcher would like to suggest the following practical things: 
The English teachers at SMK Saraswati Denpasar are suggested to make better preparation in planning and teaching English in the future either in conversation, structure as well as in reading comprehension. In this case the teacher should give more attention to the use of questions.

The English teachers are suggested to be much more concerned in teaching questions especially to construct information questions which are very important in conversation. The teachers should teach beginning the affirmative sentence, yes-no questions and Wh-questions. Then the sentence especially Wh-questions are used in guidance and free conversation, in interviews and in reading comprehension.

The English teachers are recommended to be more active and creative in implementing and experimenting different technique of language teaching depending on the particular classroom situations, atmosphere and conditions, so it is expected that the attention and the motivation of the students in learning English can be increased especially for those who get insufficient and poor grade. 


\section{REFERENCES}

Azar Betty Schampfer. 1992. Fundamental of English Grammar. New Jersey 07632, Regents / Prentice Hall A Devision of Simon and Schuster Englewood: Longman Group Ltd.

Bloom, Benjamin. 1979. Taxonomy of Educational Objective, Handbook II cognitive Domain. London: Longman Group Ltd.

Heaton, J.B. 1988. Writing English Language Test, A Practical Guide for Teacher of English as a Second Language. London: Longman Group Limited.

Hornby, A.S. 1975. Guide to Pattern and Usage in English. London: Oxford University Press.

Kerlinger, L. 1974. Paper in Interlanguage: Occasional Paper. Singapore: SEAMEO Regional Language Sentence.

Nunan, David. 1992. Research Method in Language Learning. USA: Cambridge University Press.

Palmer, F.R. 1994. Grammatical Roles and Relations. Cambridge: Cambridge University Press. 